\title{
Towards social justice in highly complex schools in Catalonia, Spain
}

\section{Patricia Silva, Serafín Antúnez and Charles L Slater (1)}

\begin{abstract}
This study investigated social justice from the point of view of school directors, teachers, and parents. We chose two schools that were undergoing major demographic changes because of increased immigration into Catalonia, Spain. They were both classified as "schools of maximum complexity" because of their socio-economic characteristics. The research questions focused on how directors, teachers, and parents give meaning to social justice and what actions they take to achieve it. Teachers and principals adopted practices that have been described in leadership literature as transformational, such as building trust and challenging the process; they only occasionally showed transformative practices like those described by Santamaria (2014) as applied critical leadership (ACL). They were motivated by seeing the needs of migrant families and students with special needs. They seriously considered social cohesion and believed that all students should be given the same opportunities and treated fairly. While these principals wanted to guide teachers to see their work in new ways and develop practices to address the needs of a changing student population, they did not reflect on the connection between day-to-day problems and the larger social system. This critical perspective is essential to ACL.
\end{abstract}

\section{Keywords}

Social justice, school principal, diversity, transformative leadership, Spain

The importance of school leadership in addressing the needs of marginalized populations is receiving increased attention around the world. (Belavi and Murillo, 2016; Bogotch and Shields, 2014). The International Study of Leadership Development Network (ISLDN) has been concerned with distribution of resources, recognition of people of different backgrounds, access to power, and inclusion since its founding in 2008 (Cerdas-Montano et al. 2018; Gurr et al. 2018; Jacobson and Notman, 2018; Okilwa and Barnett 2018; Robertson, 2017; Sun, 2018).

A recent study on school leadership and child poverty in schools was carried out in western Andalusia, Spain. Llorent-Bedmar et al. (2019) found that teachers were in urgent need of preparation to work with students at risk of social exclusion, and principals needed greater autonomy

\section{Corresponding author:}

Charles L Slater, Department of Educational Leadership, California State University, Long Beach, I250 Bellflower Blvd, Long Beach, CA 90803, US.

Email: charles.slater@csulb.edu 
Educational Management Administration \& Leadership XX(X)

to work with teachers to improve instructional practices. Llorent-Bedmar et al. (2019) make an important contribution on the technical aspects of school leadership in Spain, but they do not discuss issues of social justice directly.

This paper focuses on social justice in two schools in Catalonia, Spain, that have faced new challenges caused by the arrival of immigrant families from all over the world. The research questions focused on how directors, teachers, and parents give meaning to social justice and what actions they take to achieve it. Our theoretical framework was applied critical leadership (ACL) developed by Santamaria (2014).

In recent years, education systems in general and schools in particular have faced an urgent need to support families overwhelmed by social challenges that go beyond the curriculum. Tejada (2000:1) points out that social, cultural, and economic changes have a decisive impact on educational approaches and require structural modifications and changes in practices. Research studies, such as those by Salimbeni (2011) have shown that student performance and learning are influenced by the interactions that students have with all social actors, specifically with their families. Siqué (2006) and Boylan and Woolsey (2015) add that such interactions can be altered when there is great linguistic and cultural diversity.

According to UNESCO (CICS/IED/UNESCO, 2016), poverty, inequality, and social justice are closely interrelated. Inequity is the starting point, and issues related to the economy, such as differences in income levels, living standards, or employment are compounded by discrimination based on gender, ethnicity, and race or religion. The report draws attention to those aspects which are the most important factors determining social exclusion and discrimination.

In Spain, between 1996 and 2009, the number of immigrants increased by a factor of six. In a few years immigrants went from being $3 \%$ to $14 \%$ of the population. More specifically, Catalonia currently hosts people from all continents. Taking into account the data provided by the Statistics Institute of Catalonia (IDESCAT, 2018), in 2017 the number of immigrants amounted to 1,041,362 (13.7\% of the total population of Spain).

The origins of immigrant families are diverse. The Moroccan community predominates with $19.89 \%$ of the total number of foreign residents. Romanian are $8.55 \%$; Chinese are $5.5 \%$; Italians are $4.97 \%$; and Pakistanis are $4.24 \%$. If we analyze the population by continent, there are $33.16 \%$ from Europe, $27.25 \%$ from Africa (most from North Africa), $24.81 \%$ from South America (mainly from Peru, Ecuador, or Bolivia) and 14.70\% from Asia (IDESCAT, 2018).

Groups with different cultures, lifestyles, languages, and beliefs have come in contact with each other. The great majority of the migratory waves come from marginal centers, and poor and socioeconomically disadvantaged areas.

Faced with a complex and culturally diverse reality, the European Union has set a goal of inclusion (Commission European, 2010). All faculty are expected to serve students to live together in a diverse context. The effort will have to be intensified to bring at least 20 million people out of poverty by 2020 . This idea is supported by the recent linguistic model of the educational system of Catalonia, (GenCat, 2018).

In the Spanish case, Organic Law 8/2013 (BOE No. 295) states that one of the competencies that students must develop is related to coexistence in a multicultural and diverse society. Antúnez (2004: 89) understands participation as the action of intervening in the processes of planning, execution, or evaluation of certain tasks that are developed in the school. Torres (2001) argues that families and community can participate through management and decision-making; curriculum, classroom activities, and educational support at home. This type of participation and recognition leads to social justice and democracy (Belavi and Murillo, 2016). 
For Barrientos et al. (2016) promoting participation requires: (a) assuming that the goal of education is none other than to ensure that children develop the competencies established in the curriculum; (b) recognizing that respect for cultural diversity is essential for building an effective relationship with families; (c) contributing to the construction of educational conditions in which all people and groups can promote shared activities; and (d) valuing the contributions of external professionals and families.

These contributions can be a reference that allows us to know if the practices that are developed in classrooms are shared and are part of a collective identity and, above all, are oriented under the principles of equity and social justice. However, these principles do not make sense if they are not linked to the recognition of the value of differences and greater representation in social and school life.

\section{Theoretical framework}

The field of leadership has advanced by following several models in recent years. Instructional leadership has put the responsibility for school improvement on the shoulders of the principal (Hallinger 2003). Distributed leadership emphasizes the role of teachers and those who take both a formal and informal role in creating change (Harris et al, 2007). Moral leadership calls on schools to be places of community and trust (Sergiovanni, 1992). Transformational leadership moves beyond management to make fundamental changes in people and organizations.

Kouzes and Posner (2012) helped to popularize Burns' (1978) concept of transformational leadership in the world business. They defined a transformational leader as one who inspires a shared vision; encourages collaboration and the creation of effective teams; promotes high expectations; and recognizes the work of the members of the organization. This type of transformational leadership requires a higher level of interaction among the members of an organization.

Da Costa et al. (2014) described transformational leadership as a result of increased motivation and commitment on the part of managers and professionals at the center. They argue that it is necessary to enhance the participation of all and work together. Cornejo et al. (2014) emphasize that it is fundamental to guide teams in a particular direction toward excellence and organizational learning. They point out that strategic management, communication, delegation, negotiation, conflict resolution, teamwork, and the participation of families open new possibilities.

Transformational leadership (Kouzes and Posner, 2012) has had a major impact in business and education. Being a successful manager is no longer considered to be an adequate profile for a school director. This change from static directives to negotiation and inspiration has opened the way to influence both leaders and followers to think in new ways and reflect on their own moral convictions. While laudable, transformational leadership falls short because it can be carried out without reference to conditions of social justice in the broader community. For example, a school director might inspire teachers to implement reading programs that give students greater levels of skill and help them reflect on their own moral behavior, but there might still be no reference to the social conditions in which students live and the historical conditions that keep them in poverty.

For these reasons, Shields' (2010) concept of transformative leadership goes wider because it includes a more critical perspective and equitable change in social conditions. She argues that leadership requires moral courage and activism.

Shields (2010) inspired a line of research that focuses on social justice. DeMatthews et al. (2016) studied a school leader, Mrs Donna, who established a school in Mexico along the border with the USA. She exhibited transformative leader practices, which included leadership oriented 
Educational Management Administration \& Leadership XX(X)

toward the lived experiences of marginalized communities, a connection of school lives to community lives, commitment to a view of schooling that included more than academic achievement, a priority of interaction with the community, and, most importantly for transformative leadership, a challenge of dominant ideologies.

Another school leader in northern California in the USA provided safety by protecting undocumented parents and students from the threat of deportation. She was sensitive to the culture of the community; she communicated regularly and had developed a critical consciousness (Crawford, 2017).

The transformative practices reported by De Matthews et al. (2016) and Crawford (2017) were related to the practices of culturally responsive school leadership described in a recent review of literature by Khalifa et al. (2016). Culturally responsive school leadership included critical selfawareness, culturally responsive curricula and teacher preparation, an inclusive school environment, and engagement with students and parents.

Transformative leadership is perhaps best exemplified by Santamaria's (2014) concept of ACL. It includes aspects of transformational and transformative leadership in the context of social justice. ACL is defined by the following practices: conducting critical conversations, assuming a critical race theory lens, building consensus, addressing stereotype threat, promoting academic discourse, honoring all constituents, leading by example, and establishing trust.

ACL served as a guiding theory for this study because the above practices resonated with transformative social justice leadership. We were looking for attitudes and actions that represented these practices. The transformative social justice leader would confront moral issues when necessary with critical conversations. A critical race theory would be applicable in the USA, where Santamaria's research was conducted, but we looked more broadly for oppression of any group, particularly those newly arrived in the country. We were particularly alert for subtle threats to the identity of immigrants that would affect their achievement. The leader would also have the skills of transformational leadership to build consensus of families and teachers, promote academic discussion of the mission of the school, honor all constituents, lead by example, and establish trust.

\section{Methods}

This study looked for signs of transformative social justice leadership by examining the views of school directors, teachers, and parents. We chose two schools that were undergoing major demographic changes because of increased immigration into Catalonia, Spain. They were both classified as "schools of maximum complexity" because of their socio-economic characteristics. To determine the level of "maximum complexity" the following criteria are taken into account: diversity of the school; family background; socio-economic and educational level of families; and academic results. These schools receive a higher level of resources (Departament d'Ensenyament, 2014).

The schools were located in the cities of Santa Coloma de Gramanet in the province of Barcelona, and in the city of Lleida. The two are located in the autonomous community of Catalonia, Spain. The schools were selected for their diverse migrant populations. Principals and teachers participated voluntarily, and teachers recommended parents to be interviewed.

The Santa Coloma school is located in a lower-middle class urban area. It provides services to families in disadvantaged socio-economic conditions. There are three groups of pre-school and six groups of primary school with 254 students and 20 teachers. In total there are 12 different nationalities. $10 \%$ of the students are native to Spain and $90 \%$ are children of migrant families; of these some were born in Catalonia but did not have contact with the Catalan language until they 
entered school. Students are predominantly of Moroccan origin, but there are also Romanian, Indian, Pakistani, Bangladeshi, Chinese, Ecuadorian, Bolivian, Honduran, Dominican Republican, and Nigerian students.

School two is located in the center of the city of Lleida. Traditionally, it was a school that served people of the neighborhood with a high economic and social level. Now it is a different school, hardly recognizable due to the change it has undergone. It provides services to families in disadvantaged socio-economic conditions.

There are three groups in preschool and six in primary school with 235 students, 22 teachers, and three specialist teachers. There is a psychologist from the psychological support team and a social worker who attends the school at specific times. There is a turnover of between three and four teachers each year. There is free lunch for all students who request it. In total there are 46 different nationalities. $8 \%$ of the students are native to Spain and $92 \%$ are children of migrant families. Like the school described above, some were born in Catalonia but have not had contact with the Catalan language and culture until they entered school. The students are mainly of Senegalese, Cameroonian, Algerian, or Moroccan origin. They also have students from South America. The school also is classified as "of maximum complexity".

\section{Sample}

School one. The principal (Montse) has 20 years of teaching experience. He has 12 years in management positions. He previously served as head of studies and agreed to serve because the former principal became ill and retired from school.

The teacher (Lluís) has 15 years of teaching experience. He has worked in several schools teaching first, second, fifth, and sixth grades. Currently he teaches first grade.

The mother (Fatija) is a woman who is 33 years old. She is a single parent who lives with her son. She is from Morocco and moved to Spain 20 years ago. Her son is 7 years old and was born in Barcelona. After several changes of address, they have lived in Santa Coloma for 6 years. Her son is in precarious health and has had difficulty in behavior at school. He has attended the school for the last 4 years. He currently attends second grade of primary school.

School two. The principal (Alba) has 25 years of teaching experience. She has 10 years in the center, four of them as director. She has experience in instructional management and was appointed by the inspector.

The teacher (Sergi) has 30 years of teaching experience. He has spent 9 years at the school and is currently head of studies, a position he has held for the last 4 years.

The mother (Nicole) is a woman who is 39 years old. She has two children of school age. She is from Romania and has been living in Lleida for 15 years. She is unemployed and receives family help each month from the government. Her husband works in a fruit company. The oldest of her children is in secondary school and the second is in fifth grade.

\section{Research design}

With this sample we carried out an exploratory case study, that is, an examination of preliminary issues of social justice leadership that are just beginning to be defined. The results were intended to achieve greater clarification rather than to lead to conclusions (Cribb and Gewirtz, 2003; Schwandt, 2000). It was characterized by the search for understanding social justice from the 
point of view of the participants through the systematic analysis of their narratives (Denzin and Lincon, 2005). The methods used in this study are similar to those of Theoharis (2010) who studied principals in the USA who showed commitment to social justice. The research questions were: how were the beliefs of school leaders related to transformative social justice, and how were the actions of school leaders related to transformative social justice?

An in-depth interview was used. We wanted to know the background and the reasons why the participants were interested in issues related to social justice. The interviews were transcribed and sent to the informants, so they could validate the content (Lincoln, 2001). We used the constant comparative method of Coffey and Atkinson (2005). Two researchers read each transcript twice and developed an initial list of codes. They compared the codes and agreed upon a common list of 20 codes. Then they applied the codes to each transcript and compared their results. This coding process (da Costa, et al. 2014; McMillan and Schumacher, 2005; Weitzman and Miles, 1995) led to themes related to each of the research questions. For the beliefs of the leaders, the themes were: the needs of families, migration of students, student needs, and the principle of treating students fairly. For the actions of leaders, the themes were: teacher learning, relations with the community, and social cohesion.

\section{Results}

In this section, we present the beliefs and practices of these two schools that serve as a basis for identifying elements related to transformative social justice and ACL (Santamaria, 2014). They are organized according to each of the research questions.

\section{How were the beliefs of school leaders related to transformative social justice?}

We wanted to know how people we interviewed gave meaning to social justice (Cuenca, 2012). We were interested in knowing their reasons and what motivated them to continue this pursuit. The following participants wanted to honor all constituents (Santamaria, 2014) of the school, particularly families who had recently migrated to Spain and their children who needed personal attention, as well as students with physical handicaps or autism.

Needs of families. Principal Montse expressed interest by looking at the context and needs of families.

My interest in social justice was much more awakened when I took over the leadership. I think I've always had sensitivity for others. In this school, what drives you is the need. You are in a neighborhood of people who have many social needs. The vast majority of students, as you know, are in a precarious social context. They are not native families. They come from many countries, especially from North Africa, Latin America, and, above all, China. This neighborhood contains the largest Chinese community in Catalonia. (Principal Montse, School 1)

Migration. Principal Alba's reasons stemmed from the change brought about by migration. She noted that the students' uncertainty and lack of adaptation to their new environment made her aware of being involved in a new project.

I would say that what made me change was the attitude of the children. When I arrived at this school, children had symptoms of sadness, you never saw them smile, they were never happy, and they were a 
little suspicious of the attitude of the teachers. Instead they are much closer now, always looking for your support, your love. (Principal Alba, School 2)

Student needs. Teachers Sergi and Lluís were aware of the context; they worked directly with students who needed personalized attention; and the effort they made to get ahead made them realize that it was essential to provide adequate attention to students and their families.

A couple of experiences that caused me great impact arose with disabled children. The first experience was with a girl who, despite having undergone several operations to be able to speak and only be able to use two fingers of each hand, tried to be like others and do exactly the same as they did, despite her disability. The second experience came from an autistic student who overcame his physical barriers to achieve an out-of-school success. Both experiences made me see that, despite the limitations that one may have, if he strives he can achieve many of the things that are proposed. (Teacher Sergi, School 1).

These experiences made both Teacher Sergi and Teacher Lluís realize how important it is to work under the principles of equity and social justice (Brown, 2004).

... from what I observed I wanted my educational practice to offer the same opportunities to everyone for which their parents thanked me... (Teacher Lluís, School 2)

Fair treatment of students. Honoring all constituents was also expressed in terms of fairness. Parents and teachers felt that all students should be treated the same. Parent Fatija acknowledged that the performance of faculty showed fair and equitable treatment for all students, "At school, they treat all children and families equally. I have not seen that they treat one or the other differently, regardless of origin" (Parent Fatija, School 1).

Parent Nicole pointed out that the treatment had been very fair and had met what she expected from the school and its teachers. She believed that you should "treat people well, no matter whether they are foreign or fat or whatever, they should not be treated badly... They are all the same." (Parent Fatija, School 1)

These ideas are confirmed by the opinion of Principal Montse (School 1):

In school, for sure, we have inequalities because students come from different cultures. Here there are no differences because they (parents and mothers) do not consider them so, for they are all from here, children feel this more than their parents. Most of these children do not want to go back to their country, the parents do. These children do not conceive of differences in any way; indeed, we do not demonstrate them or emphasize them, on the contrary, we always use cultural differences to integrate. (Principal Montse, School 2)

In all cases they emphasized their belief that it is important to attend to students in the same way. Recognizing that change of context is very difficult and that children require special attention has allowed teachers and managers to ensure equitable treatment, a concept that mothers point out with the expressions such as, "all are equal" or "treat all children and families alike."

Sense of responsibility and action. The experience of teachers has led to the need to assume more responsibility for their work. Ensuring that all students are able to study and have the necessary 
resources is to ensure equal opportunities for all children in school (García, 2015). Principal Alba described her approach to education in the following words:

I believe that the basic thing is to act every day, every moment, every minute, to act with justice, and not only at a certain time, in a special circumstance, but every minute. It has to be a foundational job, working and trying to make everyone happy, everyone has a pencil or an eraser. (Principal Alba, School 1)

Parent Fatija agreed with this idea:

I think the materials are different. They worry about the children having all the materials: pencils, notebooks ... In other schools that I know they do not worry so much. We pay 60 euros a year for all the materials and the child needs. That's very good. In other schools they pay 200 or more. (Parent Fatija, School 1)

In both schools, there were critical conversations (Santamaria, 2014) among teachers to challenge their own practices and find new ways of doing things. There was an explicit identification of the need to challenge traditional practices and begin to do things differently. The needs of families motivated teachers to orient their work under just principles. When they first arrived, the directors confronted teachers with the need to change. The need to do things differently was never seen by the two directors as overwhelming, but rather as a challenge and an opportunity.

When I arrived, the teachers did not assume that there would be a new reality. They did not want to see change and their lack of understanding of these children was the first things that caught my eye. That's why we started with training. (Principal Alba, School 2)

... teachers were all a little scared, not knowing what to do; what they would rather do was complain. And that's where I thought, "No, we do not have to complain," what we have to see is what is happening to us, and we will remedy it, and we will see if we have to change something. (Principal Montse, School 2)

Confronting new challenges was also mentioned by Teacher Sergi and Parent Fatija:

It coincided with a new management team arrival and they began to act in another way, with affection, with attention, with service, and the teachers began to realize that many more things were gained from this (Teacher Sergi, School 1)

At school they have information about the child that is communicated from the social worker, from the CAP (medical center-primary care), the hospital. They know everything. They quickly know everything that happens to them... yes, they communicate quickly between them. (Parent Fatija, School 1).

The directors described the difficulties that the teachers faced:

... (it) has been hard since many teachers did not understand the changes we were experiencing. We went through many things, for example, difficulties like students who arrived without books, students who came without the minimum qualifications, who had not eaten, who did not bring basic school material such as a case, a pencil, an eraser. There were some teachers who resisted and did not understand. (Principal Alba, School 2) 
When teachers were confronted, they felt uncomfortable in their attempt to address the needs of a new immigrant population.

And in that time, what I observed was a great discomfort on the part of the teaching staff because just as the population began to change. Until then there had been an immigrant population, immigrant but migrated from other parts of Spain. These were people who had been here for some years, and were already quite adapted, working people, people within a normal area of the outskirts of Barcelona. The foreign population was just beginning to arrive in large numbers, of course, nothing like the present...(Principal Montse, School 2)

The assessments of the two directors were not unfounded because, in fact, there were uncertainties in the teaching staff. They were facing a reality that they had never lived and for which they were not prepared.

Evans (2007) concluded that educational leaders have a social and moral obligation to confront inequitable practices and create more equitable processes and outcomes for students of different racial, socio-economic, gender, and cultural groups. Palacín (2008: 700) states that teachers invest all their energies in order to work coherently and effectively in such a complex context, but the working methodologies that they usually use are not always effective in the new reality.

In our study these ideas about the back and forth struggle to confront inequities were confirmed. The teachers and the directors, despite the changes experienced, have been concerned with promoting new actions and trying to change the institutional culture and promote new projects.

The two cases that we present coincide with Brown's (2004) and Hafner's (2006) who suggest that leaders for social justice help students overcome school failure by helping them to make decisions and to implement actions to improve their own achievement. This is a process of "deconstruction and reconstruction," which could also be understood as reflective practice that is akin to Santamaria's (2014) practice of building consensus.

From their experience of a critical situation experienced in the school, teachers have been able to overcome fears and uncertainties and to rebuild a new educational project that benefited students by giving attention and honoring families and including them as the focus.

\section{How were the actions of school leaders related to transformative social justice?}

The analysis of the professional practices of teachers and managers showed the relationships established with students and their families. Changes in context challenged teachers to broaden their professional practice to adopt other principles in teaching. The faculty developed consensus about what needed to be done through promotion of academic discourse (Santamaria, 2014).

Promotion of academic discourse. Zaretsky (2004) raises some concerns about the absence of practical guidance for school leaders and Santamaria (2014) adds the need for academic discourse as a foundation for practical guidance. Our study coincides with these authors because teachers in both schools recognized that they did not have the tools to meet the needs of children. Teacher Sergi (School 1) said, "The main obstacle that I saw was the vision of the teaching staff. They did not know how to act." Principal Montse (School 2) said: 
The first thing we did was to get two years of training in Emotional Education, because many students arrived with many problems that they did not understand; (they wondered) why they had been uprooted from their natural environment and entered a school, in a country they did not know, in a society that they did not know and usually with parents who were both working, and those children were immersed in a different world and that caused many of them to have emotional problems, which were then reflected naturally in the day to day life of the school. (Principal Montse, School 2)

At the first meetings in September we always explain the attitude that the teacher has to take. (Principal Alba, School 2)

Trust with the community. Barrientos et al. (2016) point out that school management must base its functions in two relevant dimensions: on the one hand, manage all areas of institutional activity focusing on students and, on the other hand, promote a culture of participation with families and the community. This participation had trust as its foundation (Santamaria, 2014; Tschannen-Moran and Hoy, 2001). This idea emerged clearly from the results of our study:

I also connect social justice with the participation of citizens and decision-making, it is fundamental! There is no social justice if there is no active participation and communication of people. The family has an important role to play, without the support and involvement of parents, the student will probably not succeed. Our priority now is the families, we want them to become support for the institution. We have to focus on the emotional side of the student and his family, we do not want parents to only come forward when there are complaints or difficult situations, but (we want them to) feel part of the institution. We need to make links with parents. (Principal Montse, School 2)

Parent Fatija and Parent Nicole mentioned how the principals led by example and established trust by reaching out to parents (Santamaria, 2014):

The principal always greets you, even if you do not have an appointment. You go without a date and they always take care of you. You have to wait a little while but you enter and listen. (Parent Fatija, School 1)

Mothers who do not understand what the teachers and the director tell them received explanation many times, little by little, especially the Chinese. (Parent Nicole, School 2)

Emphasis on social cohesion. The educational administration of Catalonia considers social cohesion to be a policy priority. Several schools have incorporated it as a priority of their educational project (GenCat, 2006: 6; GenCat, 2009). Social cohesion means establishing trust among all groups (Santamaria, 2014). Action in this direction is expected to reduce social inequalities, widespread vulnerability, and social exclusion.

... in terms of social cohesion we realized that we needed to do a very important job with families, and we got families involved more with all the artistic activities because we knew that if families were involved with the school they were getting involved with society. They left their familiar, social surroundings and integrated into a much more mixed, much more varied environment, which was the environment offered by the school. All this also coincided with the fact that most of the parents remained unemployed. (Principal Montse, School 1)

Support for families has resulted in lunch grants and specific grants or savings in the purchase of books through socialization. "If you have to pay something to go on an excursion, they allow us to pay it little by little so that the child does not stay home without a trip." (Parent Fatija, School 1) "For the last three or four years, we have had used books and that helps us a lot." (Parent Nicole, School 2) 
Communication is a key to trust, and it becomes particularly challenging when working with people of multiple languages. In some cases the schools receive help to strengthen communication. Incorporating families into school life is not easy. Language is an aspect that can generate difficulties. To avoid them, schools have translators.

Another of the things we get is to have a Chinese-language translator to do interviews with Chinese families. That was very important, it's still important now, but now we do not have the money to pay it. (Principal Alba, School 2)

Despite insisting on the importance of school education, many parents, because of their particular situation, have not tightened the link with the school and that translates into little support for activities.

\section{Discussion}

The social justice leaders in this study were motivated by seeing the needs of migrant families and students with special needs. Programs for parents and interaction with them were judged in terms of social cohesion. They exhibited many of the practices of ACL (Santamaria, 2014). They confronted structural and pedagogical issues related to serving a new immigrant population. They promoted academic discourse and worked to build consensus on a direction for their schools. They honored all constituents through the establishment of trust.

They believed that students should be given the same opportunities, and all should be treated fairly. The principals wanted to guide teachers to see their work in new ways and develop practices to address the needs of a changing student population.

However, the directors, teachers, and parents in this study did not develop a critical perspective. They expressed their commitment to improve the lot of their students through an education that would meet their needs. They did not attempt to educate students about the broader reasons that caused families to flee from their homeland. They advocated for more resources but did not question the system that gave them less in the first place. They reached out to involve parents, but they did not provide opportunities to raise their consciousness and act politically. Our research questions reflect the strength of these schools to accommodate a new immigrant population as well as the limitation of helping them only to adjust to their place in society.

\section{How do social justice leaders make sense of social justice?}

Shields' (2010, 2017) conception of transformative leadership and Santamaría's (2014) ACL come from studies of socially just leaders. Critical leadership argues that people should engage in frank conversations and analyze differences (Taylor et al., 2009). The principals and teachers in this study were committed to improving the lives of students; they took action, and they achieved some degree of academic success because first they cared for their students.

And, in the end, we have raised the academic level of this school, and we are very happy, and we have received many congratulations because they begin to notice that we are at the same level of other schools of Catalonia... We know it because the tests of competences have shown us that we have gradually been putting ourselves on the same level, but of course, we have had offer care first. It is a word that would not have to be used in school, but here is primordial, performance is only understood if it is accompanied by affection and understanding. (Teacher Sergi, School 1) 


\section{What do social justice leaders do in school?}

Teachers and principals interested in social justice adopt practices that have been widely described in leadership literature as transformational, such as building trust (Bryk and Schneider, 2002) and challenging the process (Posner and Kouzes, 1993).

The principals and teachers in this study exhibited these practices.

The development of social justice leadership and advocacy may occur in stages. At first teachers were stunned by the changing world conditions that brought large numbers of immigrants to their classrooms. Some resisted and wanted to return to the past in a stage of reaction. Then they began to accept the new conditions but were unsure of what to do. They had entered a stage of inaction.

The next step was to advocate for children and families and seek out resources in a stage of action. They took small steps and began to wonder if they were making progress and if their efforts were making a difference. This was the stage of evaluation. They did not achieve the last stage, which would be to reflect on the connection between their day-to-day problems in the school and the larger social system. This is the stage of reflection to develop a critical perspective.

\section{Conclusions}

In this paper, we have provided an account of the relationship with social justice of a group of people from two schools in Catalonia. It adds to those developed in other contexts (Boylan and Woolsey, 2014).

The teachers, parents, and principals in this study were motivated by beliefs about the needs of families, concerns about increased migration of people to Spain, individual student needs, and a commitment to the general principal of fairness. This sense of responsibility led to action. Teachers assumed more responsibility for their own teaching and wanted to make sure that students had the resources that they needed. They were at times confused and uncertain when faced with challenges of a new student population, and they longed for greater preparation. Despite their doubts, they tried new projects and began to change the institutional culture. The themes of these projects were academic discourse to determine how to accommodate immigrant students, outreach to the community, and promotion of social cohesion.

We recommend the alignment of social justice with the improvement of the school, the training of teachers and managers to face the new challenges arising from the new social composition, and the analysis of implications for management to move towards the goals of social justice in Catalonia.

Paying attention to professional practices has allowed us to investigate how leaders take action and position themselves in relation to families and social justice issues. The results show that if one is interested in achieving social justice, good institutional management is essential (Antúnez, 2000, 2004). It is difficult to imagine a successful school that does not consider all the people involved in the educational task.

The management team must take the lead to promote, energize, and support all processes aimed at promoting social justice (Slater et al., 2014). The priority is to exercise transformative social justice leadership that includes critical leadership that is sustainable over time.

With this background, we are convinced that public schools are the first and most important social institutions that can help make social justice possible. They are organizations that provide a universal service, sustained and extended over time. A service that is common, for all citizens 
without exception, practically from the first months of life until the end of compulsory schooling, usually at 16 years.

Schools, therefore, are challenged to help ensure that all students, without exception, have the same opportunities to develop their competencies, especially those who are in personal and family situations more precarious and at risk of falling into social exclusion. In this context, it is not enough for a leader to promote equity within the school and treat students equally Rather, there are obligations to address the marginalization of students resulting from injustices in society, to address them in all areas, and to require a greater level of interaction among all constituents.

\section{Declaration of conflicting interests}

The authors declared no potential conflicts of interest with respect to the research, authorship, and/or publication of this article.

\section{Funding}

This research received no specific grant from any funding agency in the public, commercial, or not-for-profit sectors.

\section{ORCID iD}

Charles L Slater (D) https://orcid.org/0000-0001-6721-4415

\section{References}

Antúnez S (2000) La Acción Directiva en las Instituciones Escolares. Análisis y Propuestas. Barcelona: Horsori.

Antúnez S (2004) Organización Escolar y Acción Directiva. México: Secretaría de Educación Pública.

Barrientos C, Silva P and Antúnez S (2016) Competencias directivas para promover la participación de las familias. Educación XXV(49): 45-62. Perú. doi http://dx.doi.org/10.18800/educacion.201602.003.

Belavi G and Murillo J (2016) Educación, democracia, y justicia social. Revista Internacional de Educación Para la Justicia Social (RIEJS). 5(1): 13-34.

BOE Núm. 295. Ley Orgánica 8/2013, de 9 de Diciembre, Para la Mejora de la Calidad Educativa. Sec. I. Pág. 97858. Available at: http://www.boe.es/boe/dias/2013/12/10/pdfs/BOE-A-2013-12886.pdf (accessed 22 January 2020).

Bogotch I and Shields CM (eds) (2014) International Handbook of Educational Leadership and Social (In) Justice. Dordrecht, Netherlands: Springer.

Boylan M and Woolsey I (2014) Teacher education for social justice: mapping identity spaces. Teaching and Teacher Education 46(2015): 62-71.

Bryk A and Schneider B (2002) Trust in Schools: A Core Resource for Improvement. Russell Sage Foundation. Brown K (2004) Leadership for social justice and equity: weaving a transformative framework and andragogy. Educational Administration Quarterly 34(4): 77-108.

Burns JM (1978) Leadership. New York: Harper \& Row.

CICS/IED/UNESCO (2016) Informe Mundial Sobre Ciencias Sociales 2016 - Afrontar el Reto de las Desigualdades y Trazar Vías Hacia un Mundo Justo. Paris, Francia: UNESCO.

Coffey A and Atkinson P (2005) Encontrar Sentido a los Datos Cualitativos. Alicante. Servicio de Publicaciones, Universidad de Alicante. 
Comisión Europea (2010) EUROPA 2020, Una Estrategia Para un Crecimiento Inteligente, Sostenible e Integrador. Available at: https://eur-lex.europa.eu/legal-content/ES/TXT/?uri=LEGISSUM\%3Aem0028 (accessed 22 January 2020).

Cornejo CO, Rubilar FC, Díaz MC and Rubilar JC (2014) Culture and school leadership: key factors to develop an inclusive education. Revista Actualidades Investigativas en Educación 14(3): 524-548.

Crawford ER (2017) The ethic of community and incorporating undocumented immigrant concerns into ethical school leadership. Educational Administration Quarterly53(2): 147-179.

Cribb A and Gewirtz S (2003) Towards a sociology of just practices: an analysis of plural conceptions of justice. In: Vincent C (ed) Social Justice, Education and Identity. Routledge Falmer, 15-30.

Cuenca R (2012) Sobre justicia social y su relación con la educación en tiempos de desigualdad. Revista Internacional de Educación Para la Justicia Social (RIEJS) 1(1): 79-93.

Da Costa S, Páez D, Sánchez F, Gondim S and Rodríguez M (2014) Factors favoring innovation in organizations: an integration of meta-analyses. Revista de Psicología del Trabajo y de las Organizaciones 30(2): $67-74$.

DeMatthews DE, Edwards DB Jr, and Rincones R (2016) Social justice leadership and family engagement: a successful case from ciudad juárez, mexico. Educational Administration Quarterly 52(5): 754-792.

Denzin NK and Lincoln YS (eds) (2005) The Sage Handbook of Qualitative Research. Thousand Oaks, CA: Sage.

Departament d'Ensenyament (2014) Resolució de 21 de Maig de 2014. Relació de centres educatius classificats com de màxima complexitat. Available at: http://cgtense.pangea.org/spip.php?article3756 (accessed 22 January 2020).

Evans A (2007) Horton, highlander, and leadership education: lessons for preparing educational leaders for social justice. Journal School Leadershi 17: 250-275.

García JM (7th, January 2016) ¿cómo han afectado los años de la crisis a la justicia social en los países de la UE? La Vanguardi . Available at: http://www.lavanguardia.com/vangdata/20151222/30978112582/rank ing-justicia-social-europa.html.

GenCat (2009) Pla per a la Llengua i la Cohesió Social Educació i Convivència Intercultural. Barcelona: Generalitat de Catalunya. Departament d'Educació.

GenCat (2006) Pla per a la Inclusió i la Cohesió Social a Catalunya. Barcelona: Generalitat de Catalunya. Departament d'Educació.

GenCat (2018) El Modelo Lingüístico del Sistema Educativo de Cataluña. El Aprendizaje y el uso de las Lenguas en un Contexto Educativo Multilingüe y Multiculturall. Barcelona: Generalitat de Catalunya, Departament d'Ensenyament.

Cerdas-Montano V, García-Martínez JA and Slater CL (2018) Escuelas para la justicia social: experiencias de liderazgo en dos centros educativos costarricenses la revista ensayos pedagógicos de la universidad nacional.

Gurr D, Drysdale L, Longmuir F and McCrohan K (2018) Successful school leadership that is culturally sensitive but not context constrained. In: Murakami E, Gurr ED and Notman R (eds) Leadership, Culture and School Success in High-Need Schools. Washington, DC: Information Age Publishing, 25-43.

Hafner M (2006) Teaching strategies for developing leaders for social justice. In: Marshall \& M. Oliva (eds) Leadership for Social Justice: Making Revolution in Education. Boston: Pearson Education, 167-193.

Harris A, Leithwood K, Day C, Sammons P and Hopkins D (2007) Distributed leadership and organizational change: reviewing the evidence. Journal of Educational Chang 8(4): 337-347. 
Hallinger P (2003) Leading educational change: reflections on the practice of instructional and transformational leadership. Cambridge Journal of Educatio 33(3): 329-352.

IDESCAT (2018) Anuari D'estadística de Catalunya. Institut d'estadística de Catalunya. Available at: https://www.idescat.cat/poblacioestrangera/?geo $=$ cat $\&$ nac $=a \& b=11 \#$ Plegable $=$ geo.

Jacobson S and Notman R (2018) Leadership in early childhood education (ECE): implications for parental involvement from new zealand. International Studies in Educational Administration 46(1): 86-101.

Khalifa MA, Gooden MA and Davis JE (2016) Culturally responsive school leadership: a synthesis of the literature. Review of Educational Research 86(4): 1272-1311.

Kouzes JM and Posner BZ (2012) The Leadership Challenge. Hoboken, New Jersey: John Wiley \& Sons.

Lincoln Y (2001) Emerging criteria for quality in qualitative research. In: Denzin M and Lincoln Y (eds) American Tradition in Qualitative Research. London: Sage Publications, 108-120.

Llorent-Bedmar V, Cobano-Delgado V and Navarro-Granados M (2019) School leadership in disadvantaged contexts in spain: obstacles and improvements. Educational Management Administration \& Leadership 47(1): 147-164.

McMillan J and Schumacher S (2005) Investigación Educativa. Madrid: Pearson educación.

Okilwa NS and Barnett BG (2018) Four successive leaders' response to a high needs urban elementary school context. International Studies in Educational Administration 46(1): 45-85.

Palacín MP (2009) La diversidad cultural en el aula: un reto, una oportunidad. In: El Profesor de Español LEL2: Actas del XIX Congreso Internacional de la Asociación Para la Enseñanza del Español Como Lengua Extranjera (ASELE): Cáceres, 24-27 de Septiembre de 2008. Servicio de Publicaciones. ASELE, 699-708.

Posner BZ and Kouzes JM (1993) Psychometric properties of the leadership practices inventory-updated. Educational and Psychological Measuremen 53(1): 191-199.

Robertson S (2017) Leading a school merger in a high needs setting. In: McNae R Morrison M and Notman R (eds) Educational Leadership in Aotearoa New Zealand: Issues of Context and Social Justice. Wellington, New Zealand: NZCER Press, 143-158.

Salimbeni O (2011) Escuela y comunidad. Participación Comunitaria en el Sistema Escolar. Tendencias Pedagógica 17: 19-32.

Santamaría LJ (2014) Critical change for the greater good multicultural perceptions in educational leadership toward social justice and equity. Educational Administration Quarterly 50(3): 347-391.

Schwandt T (2000) Three epistemological stances for qualitative inquiry: interpretivism, hermeneutics and social constructionism. In: Denzin Y and Lincoln Y (eds) Handbook of Qualitative Research. Thousand Oaks, CA: Sage, 189-213.

Sergiovanni TJ (1992) Moral Leadership: Getting to the Heart of School Improvement. San Francisco, CA: Jossey-Bass Inc., Publishers.

Shields C (2010) Transformative leadership: working for equity in diverse contexts. Educational Administration Quarterly 46(4): 558-589.

Siqué C (2006) Práctica educativa y diversidad lingüística. Revista Interuniversitaria del Profesorad 20(2): 81-93.

Slater CL, Potter I, Torres N and Briceño F (2014) Understanding social justice leadership: an international exploration of the perspectives of two school leaders in costa rica and england. Management in Education 28(30): 110-115.

Sun A (2018, April). Social justice leadership in urban schools. Paper presented at the Thetheannual Convention of American Educational Research Association (AERA), New York.

Taylor E, Gillborn D and Ladson-Billings G (2009) Foundations of Critical Race Theory in Education. 
Tejada J (2000) La educación en el marco de una sociedad global: algunos principios y nuevas exigencias. Profesorado, Revista de Currículum y Formación del Profesorado 4(1): 1-13.

Theoharis G (2010) Disrupting injustice: principals narrate the strategies they use to improve their schools and advance social justice. Teacher College Record 112 (1): 331-373.

Torres R (2001) Participación Ciudadana y Educación. Una Mirada Amplia y 20 Experiencias en América Latina. Available at: http://goo.gl/ssaaBE.

Tschannen-Moran M and Hoy AW (2001) Teacher efficacy: capturing an elusive construct. Teaching and Teacher Educatio 17(7): 783-805.

Weitzman EA and Miles MB (1995) Computer Programs for Qualitative Data Analysis. A software sourcebook. Thousand Oaks, CA: Sage Publications.

Zaretsky L (2004) A principal's reaction. Journal of School Leadership 14(5): 564-572.

\section{Author biographies}

Patricia Silva is Lecturer at the Department of Pedagogy and Psychology, Faculty of Education, Psychology and Social Work, University of Lleida, Spain. Email: silva@pip.udl.cat

She is a member of the consolidated research group EDO-UdL and she is an author of scientific papers related to school organization and management and online teaching. She is an instructor in subjects related to management and teacher training. She was honored with the Jaume Vicens Vives 2012 award in recognition of Improvement in University Teacher Quality. She was the coordinator of the Master in Management and Management of Educational Centers at University of Barcelona from 2008 to 2014.

Serafín Antúnez is Professor at the Department of Didactic and Educational Organization, Faculty of Education, University of Barcelona (UB), Spain. Email: santunez@ub.edu

$\mathrm{He}$ is director of the Master in Management and Management of Educational Centers of this university. He has worked as a teacher, school director, and professor, and as director of the University School of Teachers and deputy director of the Institute of Educational Sciences of the UB. He has written several books and articles on organization and management of educational institutions, management training and teaching staff. He participates in research and national and international training projects for teachers, school administrators, supervisors and people responsible for initial and ongoing teacher training in Europe and Latin America.

Charles L Slater is Professor at the Department of Educational leadership, California State University Long Beach, 1250 Bellflower Blvd, Long Beach, CA 90803, USA. Email: charles. slater@csulb.edu

He previously served as superintendent of schools and received his Ph.D. from the University of Wisconsin-Madison. He teaches and conducts research in educational leadership and recently served as visiting professor at the University of Barcelona. He has collaborated with colleagues to publish studies about leadership in Costa Rica, Mexico, Korea, Spain, and the USA. 